\title{
PENGARUH PENGGUNAAN IGNITION BOOSTER 9POWER TERHADAP PERFORMA SEPEDA MOTOR
}

\author{
(1)Imam Prasetyo, (2) Naluri Jagat \\ (1)(2) Program Studi Teknik Mesin, Universitas Muhammadiyah Pekajangan Pekalongan \\ Jl. Raya Pahlawan No. 10 Kajen - Kab. Pekalongan \\ Email : Imamprasetyo27@gmail.com
}

\begin{abstract}
Abstrak
Salah satu untuk memperoleh performa yang optimal pada kendaraan bermotor, faktor yang paling berpengaruh adalah sistem pengapian yang baik dan bahan bakar yang baik. Salah satu komponen yang dapat menambah kinerja pengapian yaitu ignition booster 9Power. Penelitian ini bertujuan untuk mengetahui pengaruh performa yang dihasilkan dari variasi penggunaan 9power pada kendaraan. Penelitian ini menggunakan metode experimental dengan menggunakan alat uji dynamometer untuk menghasilkan data. Pengujian ini dilakukan dengan menambahkan variasi jumlah 9power yaitu tanpa 9power, 4 buah 9power dan 5 buah 9power. Berdasarkan dari hasil pengujian daya maksimum yang didapat 5 buah 9power sebesar 17.4 HP pada putaran mesin $10061 \mathrm{rpm}$ lebih besar dari pada daya maksimum yang didapat tanpa 9power sebesar $16.8 \mathrm{HP}$ pada putaran mesin $10721 \mathrm{rpm}$, lalu untuk torsi maksimum yang didapat 5 buah ignition booster 9power sebesar 13.36 NM pada putaran mesin $8607 \mathrm{rpm}$ lebih besar dari pada torsi maksimum yang didapat dengan tanpa ignition booster 9power sebesar 12.91 NM pada putaran mesin $7793 \mathrm{rpm}$. Dari hasil penggunaan ignition booster 9power dengan jumlah yang berbeda didapat 5 buah yang optimal dibandingkan dengan tanpa ignition booster 9power.
\end{abstract}

Kata kunci : Ignition, 9Power, Performa

\begin{abstract}
Abstrak
One of the ways to get optimal performance in a motorized vehicle, the most influential factor is a good ignition system and good fuel. One of the components that can increase ignition performance is the 9Power ignition booster. This study aims to determine the effect of performance resulting from variations in the use of 9power in vehicles. This study used an experimental method using the dynamometer test tool to produce data. This test is done by adding variations in the number of 9powers, namely without 9powers, 4 9powers and 5 9powers. Based on the results of the maximum power test, 5 9powers of $17.4 \mathrm{HP}$ at engine speed of $10061 \mathrm{rpm}$ are greater than the maximum power obtained without 9power of $16.8 \mathrm{HP}$ at $10721 \mathrm{rpm}$, then for maximum torque, 5 ignition boosters are obtained for 9power. $13.36 \mathrm{NM}$ at $8607 \mathrm{rpm}$ engine speed is greater than the maximum torque obtained without 9power ignition booster of $12.91 \mathrm{NM}$ at $7793 \mathrm{rpm}$ engine speed. From the results of using a 9power ignition booster with different numbers, it was found that 5 units were optimal compared to those without 9power ignition booster.
\end{abstract}

Kata kunci : Ignition, 9Power, Performance 


\section{PENDAHULUAN}

Perkembangan ilmu pengetahuan dan teknologi terus mengalami kemajuan yang pesat. Perkembangan teknologi yang semakin pesat di bidang transportasi berdampak pada peningkatan minat masyarakat untuk mendapatkan performa terbaik pada kendaraannya khususnya sepeda motor. Performa motor dapat diketahui dengan dua parameter utama yaitu torsi dan daya yang dihasilkan.

Salah satu faktor sistem pengapian yang kurang baik akan menyebabkan pembakaran yang terjadi di dalam ruang bakar menjadi kurang sempurna, sehingga torsi dan daya pada poros roda yang dihasilkan kurang optimal.

Untuk memperoleh performa yang optimal pada kendaraan bermotor, faktor yang paling berpengaruh adalah sistem pengapian yang baik dan bahan bakar yang baik. Salah satu komponen yang dapat menambah kinerja pengapian yaitu ignition booster 9Power. 9Power merupakan alat yang dipasang pada kabel busi untuk memaksimalkan hasil pengapian sehingga dapat meningkatkan performa pada motor.

Dengan permasalahan seperti itu telah mendorong kemajuan pada sistem pengapian untuk aplikasi performa mesin. Dalam penelitian penggunaan 9power pada kabel busi telah diteliti secara luas dan dianggap sebagai booster pengapian yang potensial untuk sistem pengapian. Sehingga 9Power mungkin menjadi alternatif booster pengapian dan banyak studi yang di lakukan untuk mengembangkan sistem pengapian. 9Power memiliki sejumlah keunggulan selain menambah performa juga dapat menghemat bahan bakar karena 9Power terbuat dari mangan, karbon dan magnesium yang bersifat konduktor dan magnet sehingga menghasilkan arus listrik yang lebih cepat dan pembakaran yang sempurna.
Beberapa fakta penelitian mencatat bahwa ada jumlah penggunaan 9power memiliki kinerja yang optimal salah satunya Abdullah (2015), Penelitian yang pernah dilakukan yang berjudul Pengaruh penggunaan 9power terhadap daya pada sepeda motor. Yang dilakukan penelitian ini adalah memasangkan 9power 1 buah, 2 buah, dan 3 buah untuk mengetahui hasil pada sepeda motor. Dari penelitian tersebut bahwa daya terendah yang dihasilkan standar adalah 3,95 HP pada putaran mesin $1500 \mathrm{rpm}$ dan daya tertinggi yang dihasilkan adalah 9,22 HP pada putaran mesin $4500 \mathrm{rpm}$. Daya yang dihasilkan sepeda motor menggunakan 9power 1 buah, 2 buah, dan 3 buah lebih besar dari pada sepeda motor standar atau yang tidak menggunakan 9power. Daya terendah yang dihasilkan menggunakan 3 buah 9power adalah 4,95 HP pada putaran mesin $1500 \mathrm{rpm}$ dan daya tertinggi yang dihasilkan adalah 9,54 HP pada putaran mesin $4500 \mathrm{rpm}$.

Berkaitan dengan uraian diatas, penelitian ini merujuk daripada penelitian yang dilakukan oleh Abdullah (2015), dengan perbedaan pada variasi jumlah 9power yaitu tanpa 9power, 4 buah 9power dan 5 buah 9power. Parameter yang diteliti pada performa yaitu daya dan torsi. Maka penelitian lanjutan ini bertujuan mengevaluasi hasil performa khususnya daya dan torsi untuk mengukur pengaruh penggunaan dari ignition booster 9Power. Penelitian ini diharapkan menjadi bahan kajian dan informasi mengenai pengaruh penggunaan ignition booster 9power terhadap daya dan torsi pada kendaraan bermotor. 
p-ISSN 2502-4922,e-ISSN 2615-0867

\section{METODE PENELITIAN}

\section{Alat dan Bahan}

Bahan bahan yang digunakan pada pengujian adalah sepeda motor Satria F 150 FI tahun 2016 dan Booster 9power, sedangkan untuk alat yang digunakan untuk mengukur daya dan torsi pada sepeda motor yaitu dynamometer. Penelitian ini dilakukan dengan menambahkan jumlah 9power pada kabel busi yang bertujuan untuk mengetahui pengaruh penggunaan 9power pada kendaraan tersebut sehingga dapat menghasilkan daya dan torsi yang optimal.

\section{Tempat dan Waktu Penelitian}

Penelitian ini untuk pengambilan data dilakukan pada Bengkel AR SPEED berlokasi di Jl. Halmahera Raya, Ungaran Kab. Semarang. Waktu penelitian dilaksanakan pada bulan maret 2020 sampai dengan selesai.

\section{Variabel Penelitian}

1. Variabel terikat pada pengujian ini adalah Daya dan Torsi.

2. Variabel bebas pada pengujian ini adalah menggunakan 4 buah Ignition Booster 9Power dan 5 buah Ignition Booster 9Power.

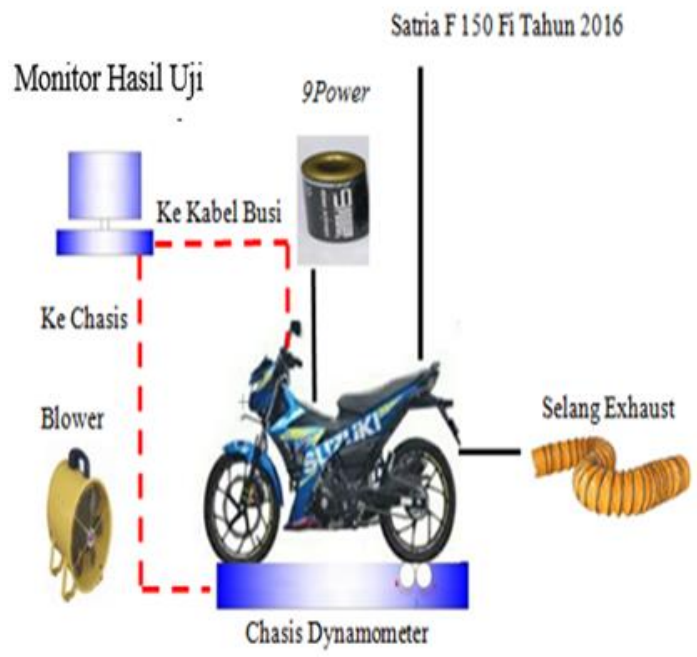

Gambar 1. Skema Pengujian

\section{HASIL DAN PEMBAHASAN}

Analisis hasil pengujian daya terhadap variasi jumlah ignition booster 9power

Berdasarkan hasil pengujian daya, maka selanjutnya dibuat ke dalam bentuk grafik untuk mempermudah dalam menganalisis hasil pengujian. Hasilnya seperti dibawah ini :

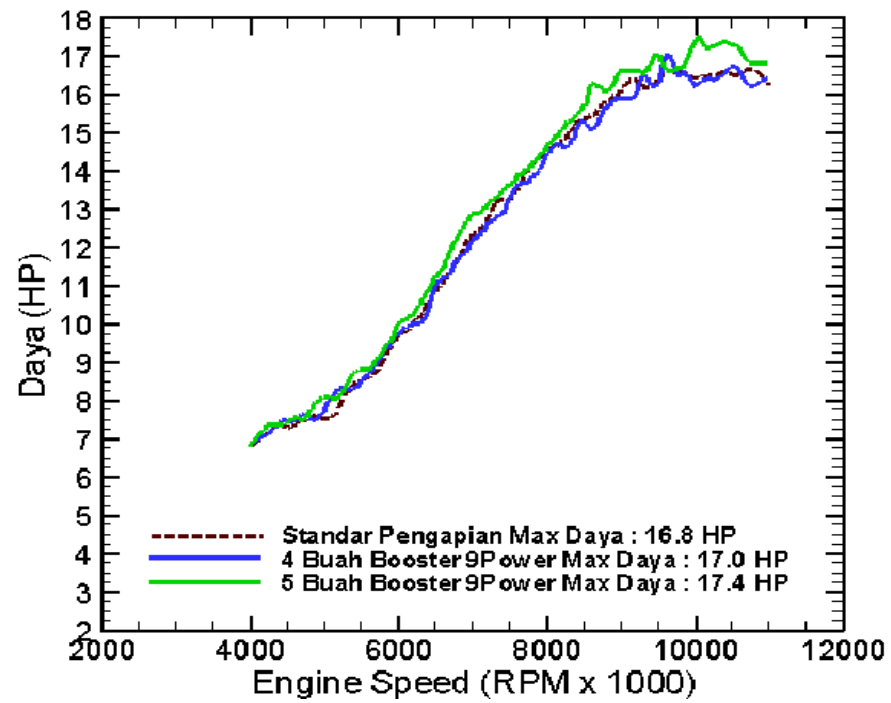

Gambar 2. Grafik Hubungan Daya

Terhadap Putaran Mesin dengan

Menggunakan Variasi Jumlah Ignition Booster 9Power

Dari grafik diatas bisa dilihat daya dimulai terukur ketika mesin $4000 \mathrm{rpm}$. Daya maksimum yang dihasilkan tanpa ignition booster 9power didapat besaran daya $16.8 \mathrm{HP}$ pada putaran mesin 10721 rpm, daya maksimum yang dihasilkan dengan menggunakan dengan 4 buah ignition booster 9 power didapat besaran daya 17.0 HP pada putaran mesin 10070 rpm, sedangkan untuk daya maksimum yang dihasilkan dengan menggunakan 5 buah ignition booster 9power didapat besaran daya 17.4 HP pada putaran mesin 10061 rpm. Maka dari grafik diatas menunjukan adanya peningkatan daya dengan penggunaan ignition booster 9Power. 
Analisis hasil pengujian torsi terhadap variasi jumlah ignition booster 9power

Berdasarkan hasil pengujian torsi, maka selanjutnya dibuat ke dalam bentuk grafik untuk mempermudah dalam menganalisis hasil pengujian. Hasilnya seperti dibawah ini :

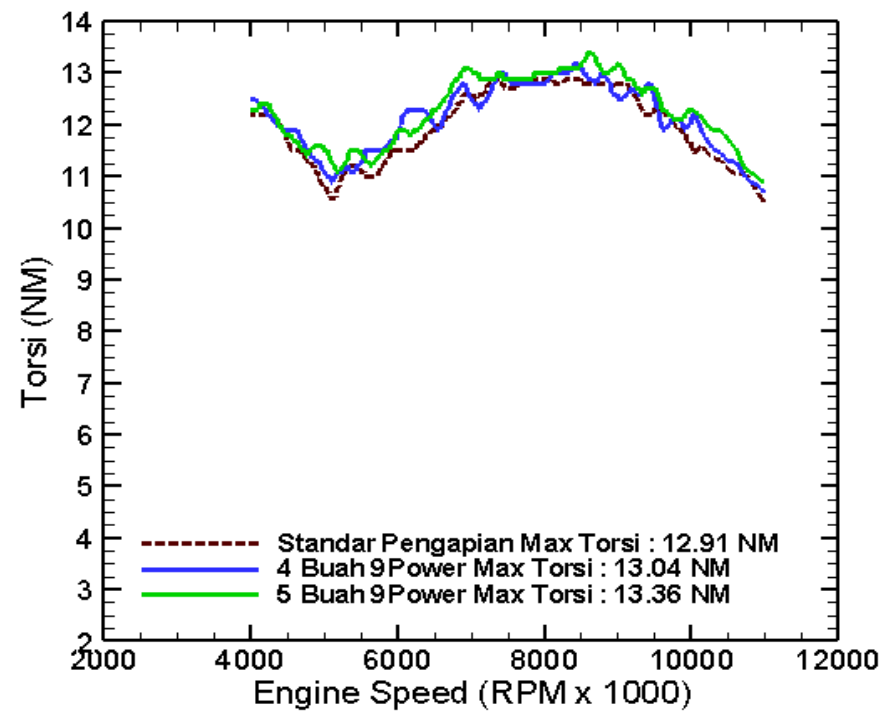

Gambar 3. Grafik Hubungan Torsi Terhadap Putaran Mesin dengan Menggunakan Variasi Jumlah Ignition Booster 9Power

Dari grafik diatas bisa dilihat torsi mulai terukur ketika mesin $4000 \mathrm{rpm}$. Torsi maksimum yang dihasilkan tanpa ignition booster 9power didapat besaran torsi $12.91 \mathrm{NM}$ pada putaran mesin $7793 \mathrm{rpm}$, torsi maksimum yang dihasilkan dengan menggunakan dengan 4 buah ignition booster 9 power didapat besaran torsi $13.04 \mathrm{NM}$ pada putaran mesin 8424 rpm, sedangkan untuk torsi maksimum yang dihasilkan dengan menggunakan 5 buah ignition booster 9power didapat besaran torsi 13.36 NM pada putaran mesin 8607 rpm. Maka dari grafik diatas menunjukan adanya peningkatan torsi dengan penggunaan ignition booster 9Power.

\section{KESIMPULAN}

Dari hasil data yang didapat setelah melakukan pengujian dapat disimpulkan sebagai berikut :

1. Penggunaan ignition booster 9power daya dan torsi maksimum yang dihasilkan 4 buah ignition booster 9 power didapat sebesar daya 17.0 HP dan 5 buah ignition booster 9power didapat sebesar daya 17.4 HP pada daya, sedangkan pada torsi sebesar 13.04 NM dan 13.36 NM lebih baik dari pada daya dan torsi yang dihasilkan tanpa ignition booster 9power.

2. Setelah dilakukan pengujian pada penggunaan jumlah 5 buah ignition booster 9power lebih optimal hasilnya dibanding tanpa ignition booster 9power, dilihat dari daya maksimum yang di hasilkan oleh 5 buah ignition booster 9power sebesar 17.4 HP lebih besar dari pada daya maksimum yang dihasillkan tanpa ignition booster 9power sebesar 16.8 HP dan lalu untuk torsi maksimum yang dihasilkan oleh 5 buah ignition booster 9power sebesar $13.36 \mathrm{NM}$ lebih besar dari pada daya maksimum yang dihasilkan tanpa ignition booster 9power sebesar $12.91 \mathrm{NM}$.

\section{REFERENSI}

[1] B. D. Triatmojo, "Pengaruh Pemasangan Ignition Booster Pada Kabel Busi Dengan Variasi Koil Terhadap Performa Dan Konsumsi Bahan Bakar Pada Sepeda Motor," Skripsi, pp. 1-71, Universitas Negeri Semarang, 2016.

[2] I. S. Y. Efendi, "Laporan Penelitian Tidak Dipublikasikan Peningkatan Performa Sepeda Motor Dengan Variasi CDI Programmable," Jurnal Science Tech, vol. 1, no. 1, p. 1-12, 2015.

[3] N. R. Ilham Fahrudin, Husin Bugis, "Penggunaan Ignition 
Booster Dan Variasi Jenis Busi Terhadap Torsi Dan Daya Mesin Pada Yamaha Mio Soul Tahun 2010," Jurnal fkip Universitas Sebelas Maret Surakarta, pp. 1-6, 2012.

[4] S. S. Salatin, "Pengaruh Diameter Kawat Elektromagnet Pada Saluran Bahan Bakar Dan Pemasangan 9power Pada Kabel Busi Terhadap Torsi Dan Daya Pada Sepeda Motor Yamaha Jupiter Z Tahun 2007," Jurnal Ilmiah Pendidikan Teknik Mesin, vol. 3, no. 2, 2014.

[5] Zulefendi, "Analisa Penggunaan Ignition Booster 9Power Terhadap Output Tegangan Coil Pada Sistem Pengapian Sepeda Motor 4 Langkah." Jurnal Ranah Research,vol. 1, issue. 3, pp. 536540, 2019.

[6] Haslim. 2010. Cara Kerja 9Power. Diperoleh: 9 September 2015, dari http://9powermax.blogspot.com/: diakses tanggal 9 September 2015.

[7] J. J. Abdullah, "Pengaruh Penggunaan 9power Terhadap Daya Pada Sepeda Motor,"Skripsi, pp.1, Universitas Negeri Malang, 2015.

[8] Sumarno, "Teknik dan Bisnis Sepeda Motor" Modul, Diklat Berbasis Kompetensi Malang, p.118, 2018.

[9] Barenschot BPM, Arends $\mathrm{H}$. 1996. "Motor Bensin" Artikel Skripsi Universitas Nusantara PGRI Kediri, Jakarta : Erlangga, 2018. 